DOI 10.15290/cnisk.2017.01.02.05

\author{
DR BARBARA DRAPIKOWSKA
}

Akademia Sztuki Wojennej

\title{
Udział kobiet żołnierzy w misjach poza granicami kraju w Iraku i Afganistanie
}

\begin{abstract}
Streszczenie
Artykuł został poświęcony problematyce udziału personelu żeńskiego w misjach poza granicami kraju w Polskich Kontyngentach Wojskowych w Iraku i Afganistanie. W pierwszej części przedstawiono dane ilościowe dotyczące ogólnego zaangażowania kobiet żołnierzy w poszczególnych misjach, $z$ uwzględnieniem zajmowanych stanowisk oraz pełnionych funkcji dowódczych. Część druga poświęcono wybranym kwestiom jakościowym związanym $z$ militarna partycypacja kobiet $\mathrm{w}$ strukturach kontyngentów wojskowych. Następnie wyszczególniono zidentyfikowane na podstawie badań czynniki ograniczajace wykonywanie przez kobiety zadań w ramach prowadzonych misji. W końcowej części sformułowano ogólne wnioski dotyczace poruszanej tematyki.
\end{abstract}

Słowa kluczowe: kobiety w wojsku • służba wojskowa kobiet • kobiety na misjach

THE PARTICIPATION OF WOMEN SOLDIERS IN COMBAT MISSIONS IN IRAQ AND AFGHANISTAN

\section{Abstract}

The following article covers the problem of women's services in the Polish Military Contingents (PMC) in Iraq and Afghanistan. The first part of the article contains a set of quantitative data about women's 
military participation with special regard to their roles in the Army. The second part is dedicated to selected aspects of women's services in military contingents. The third one discusses the main factors affecting the participation of women in the military, and the final part of the article establishes the main conclusions of this work.

Keywords: women in the Army • women's military services • women on combat missions

Poczucie bezpieczeństwa to bez watpienia jedna $z$ uniwersalnych potrzeb jednostkowych i społecznych. Jej znaczenie dostrzegł nie tylko Abraham Maslow, sporządzając piramidę potrzeb. Wiele społeczeństw żyjących na przestrzeni dziejów, walczących o niepodległość, suwerenność, a także broniących ich naruszenia przez inne podmioty, postrzegało bezpieczeństwo jako wartość nadrzędną. Zapewnienie bezpieczeństwa jest zadaniem trudnym zarówno dla jednostki, grupy społecznej, jak i dla całego państwa lub narodu. O ile niegdyś osiagnąć je było można jedynie poprzez rozlew krwi, dziś próbuje się go ograniczyć, czego wyrazem jest podejmowanie współczesnych misji i operacji wojskowych ${ }^{1}$.

Nierzadko dla osiagnięcia bezpieczeństwa używa się siły, a jedna $z$ jej $z$ nowych form sa operacje poza granicami kraju. Trend ten przyjmuje charakter globalny i można wnioskować, że stał się obecnie koniecznością niezbędną dla zapewnienia bezpieczeństwa międzynarodowego.

Siły Zbrojne Rzeczypospolitej Polskiej (SZ RP) uczestniczą w misjach poza granicami kraju już od 1953 r., kiedy to polski kontyngent został zaangażowany $\mathrm{w}$ realizację zadań operacyj-

${ }_{1} \mathrm{Na}$ gruncie formalnym należy dokonać rozróżnienia między terminami misja i operacja, które jako kategorie sztuki wojennej nie sa traktowane tożsamo. Różnice wynikają $z$ nazewnictwa stosowanego w środowisku międzynarodowym, jak również z zakresu obu pojęć. Kategoria operacji ma węższy zakres niż misja i w większym stopniu używana jest do podkreślenia militarnego charakteru podejmowanych działań. W opracowaniach, w których kwestie nomenklatury militarnej stanowia drugorzędne znaczenie, często pojęcia te używane są zamiennie. Tak samo kwestia ta zostanie ujęta w niniejszym opracowaniu. 
nych $^{2}$ na terytorium Korei. Przez prawie pół wieku udział w nich brał tylko męski personel wojskowy. Sytuacja zmieniła się dopiero $z$ chwila wejścia Polski w struktury Sojuszu Północnoatlantyckiego, co miało miejsce w 1999 r. Akces ten wiązał się z wymogiem standaryzacji armii zgodnie $z$ zasadami obowiazujacymi w NATO. Jedna ze zmian było otwarcie bram uczelni wojskowych dla personelu żeńskiego, który mógł wybrać każdą specjalność wojskowa, a nie tylko korpus medyczny czy muzyczny, jak to było wcześniej. Zmiana ta była także jednoznaczna $z$ możliwościa realizacji przez kobiety zadań operacyjnych, w praktyce jednak w rejon Iraku czy Afganistanu mogły być kierowane dopiero po ukończeniu szkoły i nabyciu minimalnego doświadczenia w służbie, dlatego też w początkowych zmianach Polskich Kontyngentów Wojskowych $(\mathrm{PKW})^{3}$ udział kobiet był najmniejszy.

Tytułem wstępu warto przypomnieć, że zaangażowanie SZ RP w Iraku trwało pięć lat, wysłano tam dziesięć zmian PKW. Z kolei w Afganistanie polscy żołnierze uczestniczyli przez ponad dziesięć lat i służyło tam piętnaście zmian PKW. Obie misje stabilizacyjne zostały poprzedzone interwencją zbrojna międzynarodowej koalicji, w której uczestniczyli także Polacy. Pierwsza interwencja, określana mianem Enduring Freedom, miała miejsce w Afganista-

\footnotetext{
2 Jednostki polskie poza granicami kraju realizują zadania operacyjne. W opracowaniu rozumiane sa jako rodzaj zadań służbowych, które $z$ kolei stanowia zbiór czynności wykonywanych przez żołnierzy zawodowych wynikajacych z zajmowanego stanowiska służbowego oraz określających wymiar czasu ich służby. Zatem zadania operacyjne to zadania służbowe wykonywane w składzie jednostek wojskowych wydzielonych do służby poza granicami kraju (Ustawa z dnia 11 września 2003 r. o służbie wojskowej żołnierzy zawodowych (tekst ujednolicony), Dz. U. z 2013 r., poz. 675, 829, 852, 1355, art. 60 oraz art. 73 ust. 1).

3 Zgodnie $z$ przepisami prawnymi wydzielone związki operacyjne lub taktyczne, a także oddziały i pododdziały sił zbrojnych moga zostać użyte do wykonywania zadań poza granicami kraju. Zadania te realizowane sa przez PKW, który zidentyfikować można jako wydzielona jednostkę SZ RP, przeznaczona decyzją Prezydenta RP (na wniosek Rady Ministrów) do udziału w operacji poza granicami kraju, tj. konflikcie zbrojnym lub dla wzmocnienia sił państwa lub państw sojuszniczych, (...) misji pokojowej, (...) akcji zapobieżenia aktom terroryzmu lub ich skutkom (Ustawa $z$ dnia 17 grudnia 1998 r. o zasadach użycia lub pobytu Sił Zbrojnych Rzeczypospolitej Polskiej poza granicami państwa, Dz. U. z 1998 r. Nr 162, poz. 1117, art. 2).
} 
nie w październiku 2001 r. i trwała do kwietnia 2002 r. W przypadku Iraku była to trwająca zaledwie dwadzieścia dni operacja Iraqi Freedom zapoczątkowana w marcu 2003 r.

Podstawę źródłową przedstawionych $\mathrm{w}$ artykule informacji stanowią źródła wywołane, obejmujące fragment wyników badań przeprowadzonych na potrzeby rozprawy doktorskiej dotyczacej udziału kobiet żołnierzy w misji w Iraku i Afganistanie ${ }^{4}$, obronionej w czerwcu 2015 r. Badania zostały zrealizowane zarówno przy wykorzystaniu technik jakościowych, jak i ilościowych. W tych pierwszych użyto techniki wywiadu swobodnego realizowanego zarówno z kobietami żołnierzami (35 osób), jak mężczyznami żołnierzami (20 osób), którzy uczestniczyli w misjach w Iraku i Afganistanie. $Z$ kolei badania ilościowe zrealizowano technika ankiety audytoryjnej na próbie 160 oficerów skierowanych do doskonalenia kompetencji zawodowych w Akademii Obrony Narodowej.

Celem opracowania jest przedstawienie udziału kobiet żołnierzy w realizacji zadań operacyjnych w PKW w Iraku i Afganistanie. Rozważania w tym zakresie obejmuja wskaźniki ilościowe, czyli dane statystyczne, oraz jakościowe - związane $z$ wykonywaniem zadań służbowych przez personel żeński.

\section{Kobiety w misjach w Iraku i Afganistanie - aspekt ilościowy}

Rozpoczynając omawianie udziału kobiet w misjach poza granicami kraju, należy wyjść od aspektu ilościowego danego zjawiska. Na podstawie obliczeń dokonanych w oparciu o dane osobowe będące w dyspozycji Dowództwa Operacyjnego Rodzajów Sił Zbrojnych dowiedziono, że udział kobiet żołnierzy w składzie porównywanych PKW był marginalny pod względem ilościowym i w większości wiązał się $z$ ich zabezpieczeniem medycznym.

${ }^{4}$ Szerzej: B. Drapikowska, Udział kobiet - żolnierzy $w$ zadaniach operacyjnych realizowanych przez Polskie Kontyngenty Wojskowe w Iraku i Afganistanie, praca dokt., Akademia Obrony Narodowej, Warszawa 2015. 
Uszczegóławiając powyższą tezę, należy zauważyć, że w misji w Iraku uczestniczyły 193 kobiety, co stanowiło 1,33\% ogółu żołnierzy wchodzacych w skład PKW. Niektóre $z$ nich realizowały zadania operacyjne więcej niż raz - dla wszystkich zmian PKW były to 24 osoby płci żeńskiej. Większość $z$ tych kobiet (piętnaście) brała udział $\mathrm{w}$ misji na dwóch zmianach PKW, nieliczne (osiem) zaś na trzech zmianach. Tylko jednej kobiecie przypadł udział w czterech zmianach. Umniejsza to ogólną liczbę kobiet (udziałów kobiet $)$ o 55 jednostek $(15 \times 2+8 \times 3+1 \times 4=55)$. W zwiąku z powyższym liczba bezwzględna kobiet, które wyjechały na misję $\mathrm{w}$ rejon Iraku w ciagu całego okresu zaangażowania SZ RP, wynosi $138(193-55=138)$.

W misji afgańskiej uczestniczyło 366 kobiet, co stanowiło już $2,2 \%$, zatem więcej niż w przypadku PKW Irak. Sa to jednak osiągnięcia pozorne, gdyż w rzeczywistości wiele kobiet uczestniczyło w misji więcej niż raz. Dla wszystkich zmian PKW były to 74 osoby płci żeńskiej. Większość $z$ nich służyła na dwóch zmianach PKW (czterdzieści kobiet), znaczna część brała udział w misji trzy razy (21 kobiet), nieliczne były obecne w składach czterech (siedem kobiet) lub pięciu zmian (trzy kobiety). Rekordowy udział w siedmiu zmianach przypadł trzem kobietom. Podobnie jak w przypadku PKW Irak ogólna liczba kobiet (udziałów kobiet) została umniejsza o 207 jednostek $(40 \times 2+21 \times 3+7 \times 4+5 \times 3+$ $7 \times 3=207) . W$ związku $z$ powyższym liczba bezwzględna kobiet, które wyjechały na misję w rejon Afganistanu, wynosi 159 (366 $207=159$ ).

$\mathrm{Na}$ podstawie tych danych statystycznych można wnioskować, że udział kobiet żołnierzy w realizacji zadań operacyjnych w PKW Afganistan był niewielki, aczkolwiek większy niż w PKW Irak. Dowiedziono jednak, że różnica ta była pozorna i wynikała $z$ uczestnictwa tych samych kobiet w wielu zmianach. Zatem obie misje pod względem ilościowego udziału kobiet nie różnią się znacząco pomimo różnic w czasie i długości trwania.

Przesunięcie punktu rozważań na grupy osobowe, do których zaszeregowane były stanowiska zajmowane przez kobiety, prowadzi do stwierdzenia, że w większości realizowały one zadania 
w grupach medycznych i okołowojskowych. Jedynie w PKW Afganistan w jednostkowych przypadkach zasiliły inne grupy osobowe - wsparcia psychologicznego, lotnicza (trzy zmiany), ekonomiczna (jedna zmiana), sprawiedliwości i obsługi prawnej (jedna zmiana). Można przypuszczać, że w grupie tej zaszeregowane były stanowiska CIMIC (Oddział Współpracy Cywilno-Wojskowej, ang. Civil Military Cooperation). Podobna sytuacja występuje w służbie wojskowej w kraju, gdzie od początków militarnej partycypacji kobiet grupy te sa najliczniej zasilane przez personel żeński.

Co więcej, kobiety także w marginalnym wymiarze realizowały funkcje dowódcze. Dane ilościowe wskazuja, że jedynie w czterech zmianach PKW Irak uczestniczyły one w dowodzeniu. W każdym $z$ omawianych przypadków udział ten nie przewyższał $1 \%$ (VI zmiana - 0,7\%, VIII i X zmiana - 0,2\%, IX zmiana - 0,1\%). Podobnie było w PKW Afganistan - na podstawie danych ilościowych można stwierdzić, że kobiety pełniły obowiazki na stanowiskach dowódczych aż w dziewięciu zmianach PKW, w żadnej $z$ nich jednak $\mathrm{w}$ grupie kobiet dowódców nie było więcej niż pięć osób. W tym miejscu należy zaznaczyć, że dane te znalazły potwierdzenie $w$ relacjach respondentek i respondentów wywiadów swobodnych, którzy przyznali, że kobiety nie były przewidziane na stanowiska dowódcze.

\section{Kobiety w misjach w Iraku i Afganistanie - aspekt jakościowy}

W celu poczynienia ustaleń o charakterze jakościowym, dotyczacych związku pomiędzy płcią a realizacją zadań operacyjnych, uczestniczki misji w Iraku i Afganistanie zostały poproszone o podzielenie się swoimi doświadczeniami i wspomnieniami. Należy zaznaczyć, że zgodnie $z$ polskim prawodawstwem wobec kobiet żołnierzy nie stosuje się żadnych praktyk różnicujących zarówno na etapie kandydackim, jak i w czynnej służbie. Niemniej jednak na podstawie informacji pozyskanych od respondentek w praktyce można się było doszukiwać pośrednich praktyk dyskryminuja- 
cych już na etapie przygotowania składu PKW. Polegało to na delegowaniu kobiet na stanowiska zwiazane $z$ praca sztabowa oraz nieuwzględnianiu ich przy stanowiskach zwiazanych $z$ bezpośrednim udziałem w walce. Regułę tę omijano jedynie dla personelu medycznego i współpracy cywilno-wojskowej, jak również dla tłumaczek. Nie zanikła ona także w późniejszych zmianach PKW Afganistan. Na potwierdzenie warto zacytować przykłady wypowiedzi kobiet w tej kwestii:

(...) nie było różnicy w delegowaniu zadań, kobiety były po prostu na innych stanowiskach niż mężczyźni, słyszałam, że zmieniło to się w późniejszym czasie i np. w Afganistanie było już inaczej.

(...) to miało miejsce przed wyjazdem, w czasie ustalania etatu. Pojawił się np. niepisany zakaz wyznaczania kobiet na stanowiska dowódcze. Na misji każdy miał swoje zadanie, które wykonywał. (...) Dowiedziałam się o tym $z$ przekazu ustnego. Krążą różne uzasadnienia, od kulturowych, że starszyzna wioski, z którą często nawiązuje kontakty dowódca, raczej nie uznaje rozmów z kobietami - nie traktuje ich jako równorzędnego partnera do rozmów, po społeczne - gdyby na misji zginęła kobieta, to ucierpiałby PR wojska i wojny afgańskiej i wiele, wiele innych, w zależności od nastawienia i kreatywności osoby uzasadniajacej, w moim przypadku zaproponowano mi stanowisko, które uważałam za wyzwanie, dlatego nie walczylam $z$ tymi zakazami.

$\mathrm{N}$ [a] p[rzykład] na prawie wszystkich zmianach $z$ założenia kobieta żołnierz nie mogła być dowódca plutonu zmotoryzowanego. Jedynie na $\mathrm{X}$ zmianie był taki przypadek i dowódca - kobieta była chwalona przez swoich żołnierzy, pomimo iż i tak byli starsi oficerowie, którzy szukali dziury w całym. Moim zdaniem liczy się przede wszystkim zdanie żołnierzy, $z$ którymi codziennie przebywasz i pracujesz, a nie kogoś, kto szerzy plotki, siedząc na krześle i nie uczestniczac w operacjach.

Kobiety biorace udział w badaniu zostały zapytane, czy w ich opinii istniała różnica w delegowaniu zadań na misji ze względu na płeć żołnierza. Postawy w tym zakresie były podzielone znaczna część badanych kobiet przyznała, że w ich otoczeniu zwracano na to uwage. W związu $z$ tym kobiety były eliminowa- 
ne $z$ niektórych prac baćź też ich udział w tym zakresie był ograniczany. Zasada ta dotyczyła zwłaszcza zadań niebezpiecznych, jak np. wyjazdów na patrole, oraz zadań bojowych, wymagajacych bezpośredniego kontaktu z przeciwnikiem. Respondentki zwróciły uwage na nieformalną regułę unikania wydawania kobietom zadań o charakterze bojowym i przeznaczania ich do pracy w sztabach. Jednakże zasada ta była stosowana w mniejszym stopniu w przypadku PKW Afganistan, gdzie praktyki różnicujące były już zdecydowanie rzadsze. Egzemplifikację tej tendencji przedstawiaja poniższe wybrane wypowiedzi respondentek:

Tak, np. zadania, które wymagały więcej siły lub wyjazdy w szczególne miejsca, powierzano mężczyznom.

$\mathrm{Na}$ zmianie, w której brałam udział, nie było żadnych kobiet w grupach bojowych, co za tym idzie, kobiety nie wyjeżdżały tyle za bazę, co mężczyźni, chyba że np. kobieta w CIMIC, wyjeżdżały też sporo tłumaczki (...).

Zauważyłam tylko $z$ czasem, że odsuwano mnie od obowiązków, nawet wtedy, gdy czułam, że im podołam, chyba dlatego, że bano się, że coś mi się stanie lub że zobaczę, że mężczyźni nie daja rady, a ja tak. Na przykład po ostrzale psycholog przyjechał tylko mnie badać, innych nie (...). Psycholog był profesjonalny, przepytał wszystkich, ale fama poszła, że tylko do mnie przyjechał, że tylko ja sobie nie radzę, ale ze służby $z$ posterunku wysuniętego mnie nie zdjęto, bo nikt nie był chętny, żeby się zamienić $z$ posterunku wewnętrznego na wysunięty.

Tak, oczywiście - kobiety zajmowały głównie stanowiska sztabowe i pomocnicze - służba zdrowia. Kobiety co do zasady nie biora udziału w zadaniach związanych $z$ bezpośrednim kontaktem $z$ przeciwnikiem.

Poprzez pryzmat zajmowanego przeze mnie stanowiska nie, generalnie istnieja przypadki w różnym delegowaniu zadań na misji dla kobiet i mężczyzn (...). Czasami przełożeni z góry zakładaja, że kobieta żołnierz nie poradzi sobie $z$ pewnymi zadaniami, motywując, iż jest kobieta, czyli nawet nie daja jej szansy i okazji, aby móc się wykazać czy sprawdzić. 
To zależy od przełożonego, czy traktuje kobietę żołnierza jak żołnierza czy kobietę (...). Ja jestem po czterech latach studiów i umiem pracować $z$ facetami i nie widziałam różnic w delegowaniu zadań dla mnie, ale widać, i nie tylko na misji, że faceci sa miękcy i nie umieją stawiać zadań kobietom. Boją się albo widzą, że nie dadzą rady, bo zachowuja się jak księżniczki, a nie jak żołnierze.

Nieznaczna większość kobiet prezentowała pogląd, iż płeć nie była czynnikiem różnicującym w trakcie delegowania zadań służbowych na misji. W ich opinii zadania rozdzielane były właściwie do zajmowanego stanowiska, bez stosowania praktyk różnicujących, co znajduje potwierdzenie w poniższych wypowiedziach respondentek:

(...) była równość i w takich przypadkach, kobiety wykonywały o wiele lepiej polecenia służbowe niż mężczyźni. Kobiety o wiele lepiej dbały o powierzony sprzęt oraz dbały o powierzone zadania, niestety znam tylko to pod względem służby medycznej (...).

(...) miałam bardzo dobrego przełożonego, nigdy nie zauważyłam odmiennego traktowania $z$ uwagi na płeć.

W komórce, w której pracowałam, były same kobiety, a dowodził nami mężczyzna, więc nie było różnic.

Każdy miał wyznaczone zadania w zależności od komórki czy drużyny, w której się znajdował. Często były to zadania równorzędne zarówno dla kobiet, jak i mężczyzn.

$\mathrm{Na}$ poczatku misji nie chcieli wystawiać nas na patrole. Po dwóch tygodniach zaczęłyśmy jeździć i tak zostało do końca.

Kobiety zapytano też, czy w ich opinii płeć miała znaczenie w zakresie wykonywania zadań służbowych. Większość respondentek bioracych udział w misjach prezentowała postawę, że płeć nie ma znaczenia w kwestii jakości wykonywanych zadań służbowych na misji. Były zdania, że czynnikiem decydujacym sa uwarunkowania osobowościowe. Nieliczne respondentki wskazały, jakoby płeć stanowiła czynnik różnicujący efekty służby w wojsku, ich postawy nie były jednak do końca wyklarowane 
i nie dyskwalifikowały żadnej $z$ populacji. Na poparcie powyższych słów warto także zacytować wypowiedzi kobiet.

I tak, i nie, zależało to od charakteru i kwalifikacji kobiet - były wśród nas kobiety, które perfekcyjnie wykonywały swoje zadania, nie raz zapewne nawet lepiej od mężczyzn, ale zdarzały się też takie, które były niekompetentne, a do tego robily $z$ siebie tzw. słodka idiotkę, co bardzo szkodziło wizerunkowi kobiet w armii.

$\mathrm{W}$ pewnym sensie tak - tak jak jest to w życiu, w zadaniach bardzo wojskowych i sprawnościowych faceci sobie lepiej radza, natomiast $\mathrm{np}$. w medycynie - zdecydowanie kobiety.

W moim odczuciu i osobistej opinii sa stanowiska w wojsku szczególnie na misji - gdzie lepiej spisywali się żołnierze - mężczyźni. Chodzi mi głównie o stanowiska dowódcze w patrolach bojowych. Nie chcę oczywiście uogólniać, bo spotkałam mężczyzn, których zastapiły kobiety z powodu lepszego przygotowania albo kondycji.

$Z$ perspektywy czasu na pewno kobiety nie mogły wszystkiego zrobić.

Kobiety ze swojej natury sa bardziej skrupulatne, zwłaszcza jeżeli poddawane sa permanentnej ocenie i opinii. Dlatego bardzo często, choć to nie jest oczywiście reguła, wkładamy dwa razy więcej pracy niż mężczyźni, po to, żebyśmy były oceniane w ich opinii jako przynajmniej przeciętne.

Przenosząc punkt rozważań na postawy prezentowane przez personel męski, w efekcie zestawienia wyników badań ilościowych i jakościowych pojawia się konkluzja, że mężczyźni akceptują udział kobiet w misjach poza granicami kraju. Większość $z$ nich widzi jednak konieczność ograniczenia dostępu do stanowisk, jakie moga one obejmować na misji. Największa akceptacja występuje $\mathrm{w}$ przypadku stanowisk zwiazanych $\mathrm{z}$ zabezpieczeniem medycznym oraz z kontaktami $z$ ludnością cywilną.

W przypadku badań jakościowych realizowanych technika wywiadu swobodnego $z$ ich analizy wynika, że postawy środowiska męskiego wobec uczestnictwa kobiet $\mathrm{w}$ misjach poza granicami kraju podzielone były na trzy grupy: 
- zwolenników nieograniczonego udziału kobiet żołnierzy w realizacji zadań operacyjnych - najmniejsza liczebnie grupa;

- zwolenników ograniczonego udziału kobiet żołnierzy w realizacji zadań operacyjnych - największa liczebnie grupa;

- przeciwników udziału kobiet żołnierzy w realizacji zadań operacyjnych.

$\mathrm{Na}$ podstawie wypowiedzi uzyskanych w trakcie wywiadów można wnioskować, że postawy w większym stopniu aprobujące przejawiali żołnierze pełniący służbę w Afganistanie. W grupie tej nie było żadnego przeciwnika obecności kobiet na misjach i dominowały postawy aprobujace ich nieograniczony dostęp do stanowisk.

Większość ankietowanych żołnierzy (trzy czwarte badanych) wyrażała pogląd, że kobiety powinny pełnić służbę poza granicami kraju. Jeżeli za punkt tych rozważań przyjmiemy rejon działań, to więcej żołnierzy przejawiało akceptację w przypadku PKW Irak. Takie statystyki moga wzbudzić zdziwienie ze względu na to, że udział kobiet w misji afgańskiej był bardziej powszechny. Biorąc jednak to pod uwagę, można wnioskować, że większa liczba kobiet w składach kontyngentów nie wpływa pozytywnie na aprobatę ich udziału w realizacji zadań operacyjnych.

\section{Udzial kobiet w misjach w Iraku i Afganistanie - czynniki ograniczające}

$\mathrm{Na}$ podstawie przeprowadzonych badań wyszczególniono czynniki stanowiące bariery ograniczajace personel żeński w realizacji zadań operacyjnych. Można je sklasyfikować w czterech kategoriach.

Pierwsza $z$ nich sa bariery mentalne wynikające $z$ nieprzygotowania żołnierzy do służby $z$ kobietami, co prowadziło do stosowania praktyk różnicujących, które $z$ jednej strony ochraniały kobiety, $z$ drugiej jednak wpływały na ich uprzywilejowanie element nieoczekiwany przez żołnierzy obu płci. Analiza uzyska- 
nych wyników pozwala stwierdzić, że kobiety nie oczekiwały ochrony przed zadaniami bojowymi i także chciały pełnić funkcje dowódcze. Niewyznaczanie ich na takie stanowiska, w ich odczuciu, ograniczało je w wykonywaniu zadań operacyjnych.

Druga grupę czynników ograniczających stanowią bariery logistyczne zwiazane $\mathrm{z}$ brakiem odpowiedniego umundurowania, dostosowanego do kobiecych warunków fizycznych, co utrudniało im realizację powierzonych zadań. Rozwiązaniem w tym zakresie mogłoby być stosowanie standardów amerykańskich, zgodnie $z$ którymi kobiece mundury polowe sa przystosowane do ich fizjonomii, przez co też nie sa uciążliwe $\mathrm{w}$ pełnieniu zadań oraz umożliwiają bezproblemowe załatwianie potrzeb fizjologicznych.

Nie bez znaczenia były także nieodciagnięcia w wyposażeniu indywidualnym polegające na braku artykułów sanitarno-higienicznych dla kobiet, niezbędnych ze względu na specyfikę płci. Na szczególna uwage zasługuje kwestia artykułów do utrzymywania higieny intymnej i odpowiedniej flory bakteryjnej kobiecych narządów płciowych. Zważywszy na warunki sanitarne oraz klimatyczne w rejonie stacjonowania PKW, a jednocześnie wrażliwość kobiecego ciała, istniało bardzo duże ryzyko chorób na tym tle, które oprócz ogólnej uciążliwości mogły skutkować negatywnymi implikacjami dla zdrowia kobiet.

Ostatnim czynnikiem ograniczającym służbę kobiet w kontyngentach w Iraku i Afganistanie był brak lekarza ginekologa w składach PKW, którego obecność była wskazana ze względu na konieczność częstego monitorowania stanu zdrowia. $Z$ powodu innej budowy anatomicznej kobiety sa o wiele wrażliwsze na uciążliwe czynniki istniejące w środowisku operacyjnym.

\section{Podsumowanie}

$Z$ uwagi na to, że kobiety w siłach zbrojnych funkcjonuja już ponad pół wieku, wzrasta również ich rola w zawodzie - od podwładnego wykonującego rozkazy po wydającego je dowódcę. Udział w misji lub operacji prowadzonej poza granicami kraju jest 
szansa dla kobiet żołnierzy na weryfikację zarówno swoich predyspozycji osobowościowych, jak i kwalifikacji zawodowych. To swego rodzaju test ukazujący jak same zainteresowane radzą sobie w sytuacjach ekstremalnych, odmiennych od codziennej służby w warunkach krajowych. Wspomniany autosprawdzian nie byłby w ogóle możliwy, gdyby nie wejście Polski w struktury NATO, które stało się nie tylko początkiem służby wojskowej kobiet, ale także dało przepustkę do sprawowania tej służby poza granicami kraju.

Zagadnieniem marginalnie podejmowanym przez badaczy, które mieści się w omawianym obszarze, jest udział kobiet żołnierzy w misjach pokojowych i stabilizacyjnych. Ocena literatury źródłowej pozwoliła stwierdzić, że temat ten dotyczy jedynie ilościowego spojrzenia na udział kobiet $\mathrm{w}$ misjach na tle populacji męskiej. Owo niewielkie zainteresowanie środowiska naukowego omawiana kwestią spowodowało, że tematyka ta jest dość niszowa i dlatego w przygotowaniu artykułu wykorzystano jedynie materiały zebrane w wyniku autorskiej aktywności badawczej.

Podejmując próbę nakreślenia ilościowego udziału kobiet w misjach, należy wyjść od spostrzeżenia, że kobiety stanowią niewielki odsetek żołnierzy realizujacych zadania operacyjne. Większość $z$ nich pełni stanowiska zaszeregowane do grupy medycznej i ogólnowojskowej mimo braku formalnych zakazów w zakresie dostępności funkcji wojskowych. Takie stanowiska sa w największym stopniu akceptowane przez mężczyzn i jednocześnie mają najdłuższa historię w zakresie służby kobiet, co być mo$\dot{z}$ e nie pozostaje bez wpływu na ich aprobatę.

$Z$ kolei jeśli punkt rozważań przeniesiony zostanie na jakościowe aspekty dotyczace wykonywania zadań operacyjnych przez kobiety żołnierze na misjach, to zauważyć należy, że w opinii żołnierzy obu płci nie ma różnic w wykonywaniu zadań służbowych, jak również $\mathrm{w}$ ich delegowaniu. Po obu stronach istnieje jednak świadomość, że wynika to $z$ różnic $w$ obsadzaniu stanowisk w kraju. Działania podejmowane przez żołnierzy sa regulowane zajmowanymi przez nich funkcjami, które $z$ kolei sa ustalane na etapie formowania kontyngentów, czyli w kraju. 
Na podstawie badań ustalono także, że praktyki różnicujące $\mathrm{w}$ oparciu o płeć stosowano $\mathrm{w}$ większym stopniu $\mathrm{w}$ Iraku niż w Afganistanie, co być może wynikało ze wzrostu doświadczenia bojowego i ogólnie wojskowego kobiet, jak również z przyzwyczajenia się mężczyzn do ich obecności, co wskazuje na niewielki, aczkolwiek dodatni kierunek $\mathrm{w}$ zakresie postaw przychylnych wojskowej służbie kobiet.

Mimo że jedynie śladowa część polskich kobiet żołnierzy uczestniczyła w misjach poza granicami kraju można wnioskować, że o ile wojsko będzie angażować się w operacje zagraniczne, o tyle coraz więcej kobiet będzie wspierać kontyngenty swymi kompetencjami. Przemawia za tym szereg argumentów, począwszy od predyspozycji samych kobiet żołnierzy, a na stanowisku NATO propagującym służbę kobiet poza granicami kraju skończywszy. Być może w niedalekiej przyszłości postanowienia Sojuszu będa także wymuszać na państwach sygnatariuszach pewne rozwiązania zmierzające do zwiększenia udziału kobiet w realizacji zadań operacyjnych.

W odniesieniu do całości problemu należy mieć na uwadze słowa Ericha Fromma: Każdemu wolno rozwijać swoiste cechy, które odróżniaja go od innych jako jednostke, jako reprezentanta danej narodowości. Równość nie oznacza negacji różnic, lecz możliwość ich najlepszego urzeczywistnienia5. Konieczne w tym względzie staje się zatem zrozumienie, że równość nie oznacza identyczności, a polega na tym, że różnice nie moga stanowić przeszkody $\mathrm{w}$ rozwoju jednostki. W przypadku realizacji zadań operacyjnych różnice pomiędzy płciami powinny być wykorzystywane $\mathrm{w}$ optymalny sposób, np. w kontaktach $z$ miejscową ludnością. Ze względu na odmienne osobowości, a także społeczna pozycję kobiety, personel żeński może realizować zadania na etapie negocjacji, co jest dla nich łatwiejsze $z$ uwagi na lepsze umiejętności komunikacyjne. Personel męski natomiast lepiej sprawdza się na etapie decyzyjnym $z$ uwagi na tradycję państw objętych misja, w której kobieta nie jest podmiotem decyzyjnym.

5 E. Fromm, Miłość, płeć i matriarchat, Poznań 1999, s. 129. 
Czynnikiem przemawiającym na korzyść udziału kobiet w kontyngentach wojskowych jest także dawanie dobrego przykładu miejscowej ludności, dla której płeć żeńska nie stanowi wartości podmiotowej. Pozycję tę akceptuja wszyscy, zarówno mężczyźni, którzy w swoich rękach skupiają decyzyjność, jak też kobiety, które przyjmuja swoja społeczna niższość. Pokazywanie przykładów kobiet ze świata zachodniego, które moga realizować zadania tak dobrze jak mężczyźni i mieć dobre wykształcenie, może być wzorem dla kobiet muzułmańskich, że wcale nie musza być gorszą kategorią społeczna, oraz dowodem dla mężczyzn, że podmiotowe traktowanie kobiet jest podejściem, które nie niesie za soba negatywnych zjawisk społecznych.

Ostatnim, lecz nie najmniej ważnym argumentem na rzecz udziału kobiet w misjach jest fakt, że tylko one moga wchodzić $\mathrm{w}$ interakcje społeczne $z$ miejscowymi kobietami. W wielu państwach objętych działaniem misji, ze względu na patriarchalne stosunki społeczne, pozycja kobiety jest dewaluowana, przez co zabrania się im również podejmowania rozmów i pobierania pomocy medycznej od osób odmiennej płci. Zasady takie w przypadku braku personelu żeńskiego w składzie kontyngentów moga doprowadzić do wykluczenia kobiet $z$ pomocy humanitarnej czy medycznej, co $z$ kolei obniża w znaczącym stopniu efektywność całej prowadzonej operacji.

\section{Bibliografia}

\section{Źródła}

Relacje kobiet żołnierzy $\mathrm{z}$ Polskich Kontyngentów Wojskowych w Iraku i Afganistanie ze zbiorów Barbary Drapikowskiej.

Ustawa $z$ dnia 11 września 2003 r. o służbie wojskowej żołnierzy zawodowych (tekst ujednolicony), Dz. U. z 2013 r., poz. 675, 829, 852, 1355.

Ustawa $z$ dnia 17 grudnia 1998 r. o zasadach użycia lub pobytu Sił Zbrojnych Rzeczypospolitej Polskiej poza granicami państwa, Dz. U. z 1998 r. Nr 162, poz. 1117. 


\section{Opracowania}

Fromm Erich, Miłość, płeć i matriarchat, Poznań: Dom Wydawniczy Rebis, 1999, ISBN 978-83-7510-763-0.

Drapikowska Barbara, Udział kobiet - żołnierzy $w$ zadaniach operacyjnych realizowanych przez Polskie Kontyngenty Wojskowe w Iraku i Afganistanie, praca dokt., Akademia Obrony Narodowej, Warszawa 2015. 